\title{
STRENGTH AND DURABILITY ASPECTS OF PARTIAL REPLACEMENT OF SAND BY GRANITE FINES
}

\author{
J.Jayavardhan.Bhandari ${ }^{1}$, Seetharam.Munnur ${ }^{2}$ \\ ${ }^{1}$ Dept of Civil Engineering, PDA College of Engineering, Gulbarga \\ ${ }^{2}$ Dept of Civil Engineering, PDA College of Engineering, Gulbarga
}

\begin{abstract}
This paper includes a study investigating the structural characteristics of concrete with the use of Granite Fines. Water to cement ratio was maintained to 0.55 throughout the project. Concrete was prepared with granite fines as a replacement of fine aggregate in 5 different percentages namely 0\%, 5\%,10\%,15\% and 20\% and relevant tests have been carried out on strength such as compressive strength, Split tensile strength and Flexural strength. For each percent 4 specimens and a total of 20 specimens were casted for 7 days and 28 days testing separately and it was arrived that optimum replacement of sand by Granite fines was $15 \%$.For the durability tests such as water absorption and porosity 15 cubes were casted and these results were compared with the conventional concrete. The test results indicates that partial replacement of sand with granite fines has beneficial effect onthe mechanical properties such as compressive strength, split tensile strength and flexural strength of concrete and also durable.
\end{abstract}

Keywords-Crushed Granite fines (CGF), Compressive strength, Split tensile strength, Flexural strength, Porosity, Water Absorption.

\section{INTRODUCTION}

Fine aggregate is an essential component of concrete. The most commonly used fine aggregate is natural river sand. The consumption of natural river sand is very high all over the world due to the extreme usage of concrete. So, the demand of natural river sand is quite high in developed and under developing countries for infrastructural growth. Due to the non-availability of sufficient quantity of ordinary river sand for making concrete is affecting the growth of constructions in many parts of the world.To overcome the scarcity and demand for river sand, scientists, researchers and practitioners in the construction industries have discovered some alternatives namely fly ash, slag, limestone powder and siliceous powder. Also crushed granite rock fines is used as an alternative to river sand in concrete. Granite fines which are the byproduct produced in granite factories while cutting huge granite rocks to the desired shapes. While cutting the granite rocks, the powder produced is carried by the water and this water is stored in tanks. After evaporation of water the granite dust remained is transported and disposed on the lands. Disposing this granite fines is a major problem in an Urban set up. Factories are situated close to the residential areas that in case random disposal of the granite fines would lead to health hazards of the people dwelling in the areas in particular and also would prove to be an environmental hazard in general. With the properties of the granite fines, i.e., its size and fineness, it can be very effectively used as a filler material in the concrete, replacing the fine aggregate which will help in filling up the pores in the concrete which is otherwise porous. Filling up of the pores by the granite fines increase the strength of the concrete and also a material which is abundantly available and which has a disposal problem can be made use effectively.

\section{EXPERIMENTAL INVESTIGATION}

\subsection{Materials Used}

Cement: OPC 43 grade cement will be used throughout the course of the project work.

Fine Aggregate: Locally available river sand belonging to zone II of IS 383-1970 with a specific gravity of 2.64 is used as fine aggregate throughout the project work.

Granite Fines: Granite fines bought from Mudgal, Dist:Raichur is used as FA for partial replacement of sand. Tested physical properties are shown in table 1 .

Table 1: Properties of Granite fines

\begin{tabular}{|c|c|}
\hline Properties & Results \\
\hline Specific Gravity & 2.63 \\
\hline Fineness modulus & 2.04 \\
\hline
\end{tabular}

Coarse Aggregate: Well graded hard broken crushed ballast stones of $12 \mathrm{~mm} \& 20 \mathrm{~mm}$ down size were used as a coarse aggregate in concrete for project work.

Water: Potable water was used in the present investigation for both casting and curing. 


\subsection{Details of Specimens Casted}

\begin{tabular}{|c|c|c|}
\hline $\begin{array}{l}\text { Type of } \\
\text { specimen }\end{array}$ & Mould size & $\begin{array}{l}\text { Total no. } \\
\text { of } \\
\text { specimens }\end{array}$ \\
\hline Cubes & $150 \mathrm{mmX150mmX150 \textrm {mm }}$ & 40 \\
\hline Cylinders & $150 \mathrm{~mm}$ dia and $300 \mathrm{~mm} \mathrm{ht}$ & 40 \\
\hline Prisms & $75 \mathrm{mmX100mmX500 \textrm {mm }}$ & 40 \\
\hline Beams & $150 \mathrm{mmX150mmX700 \textrm {mm }}$ & 6 \\
\hline
\end{tabular}

\section{Mix Proportions}

In the present work mix proportion is kept constant but sand is partially replaced by granite fines. For $\mathbf{M}_{20}$ Grade of concrete as per IS-10262 2009

$$
\begin{aligned}
& \text { w/c : cement : FA : CA } \\
& 0.55: \quad 1 \quad: 2.04 \quad: 3.29
\end{aligned}
$$
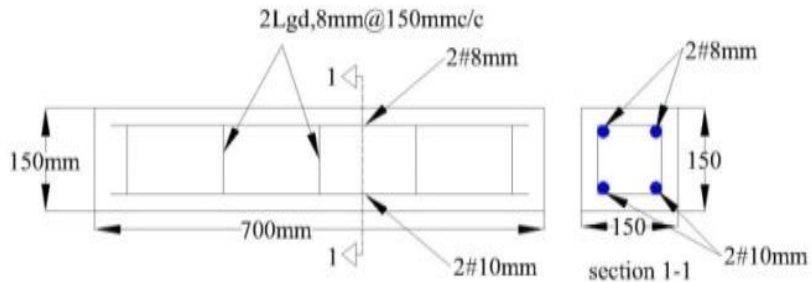

Fig 1.Reinforcement details of beam specimens

\section{Testing of Specimens}

i. For Compressive strength and Split tensile strength, the cubes and cylinders were tested in a compression testing machine of capacity $2000 \mathrm{kN}$ respectively. Graphs were plotted as shown in fig.2 and 3.Test setups are shown in Plate 1 and 2.

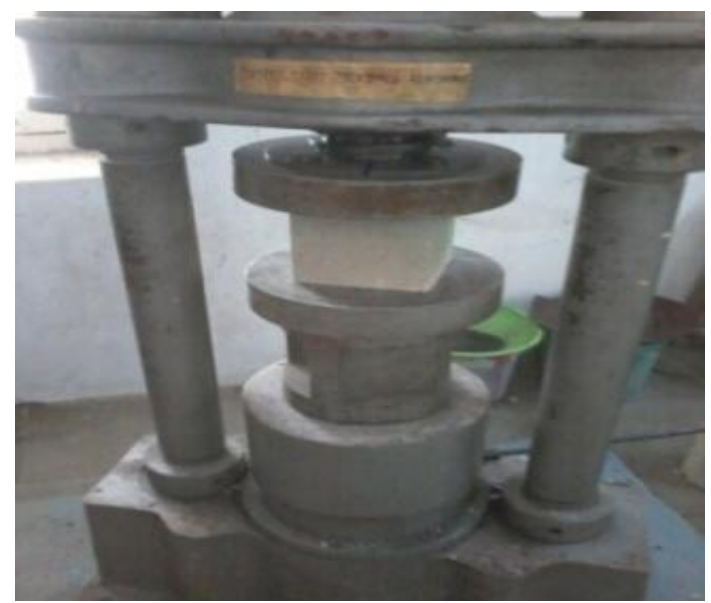

Plate 1.Test setup of Compressive strength

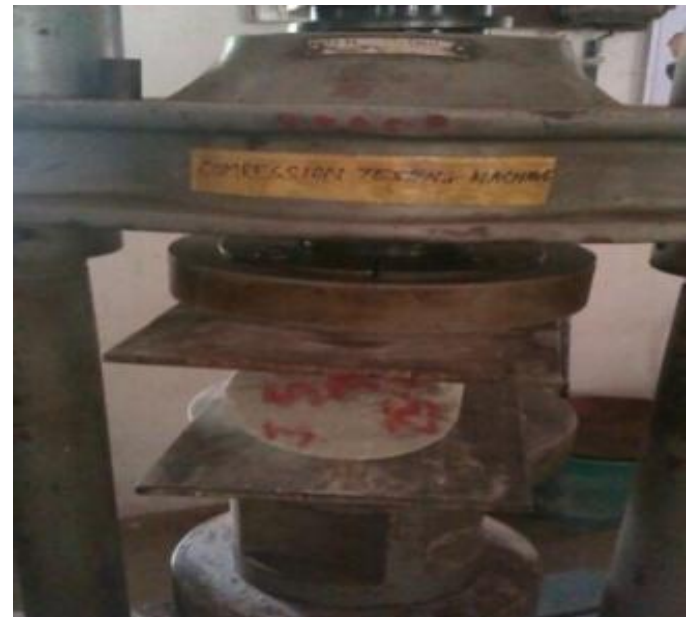

Plate 2.Test setup of Split tensile strength

ii. Flexure test for Prism is done in Universal Testing Machine and Beams are tested in loading frame using a Hydraulic jack of $500 \mathrm{KN}$ capacity by applying $2 \mathrm{KN}$ at each time. Test results of beam specimens are shown in table 2. Graphs were plotted as shown in fig.4, 5 and 6. Test setups are shown in Plate 3 and 4.

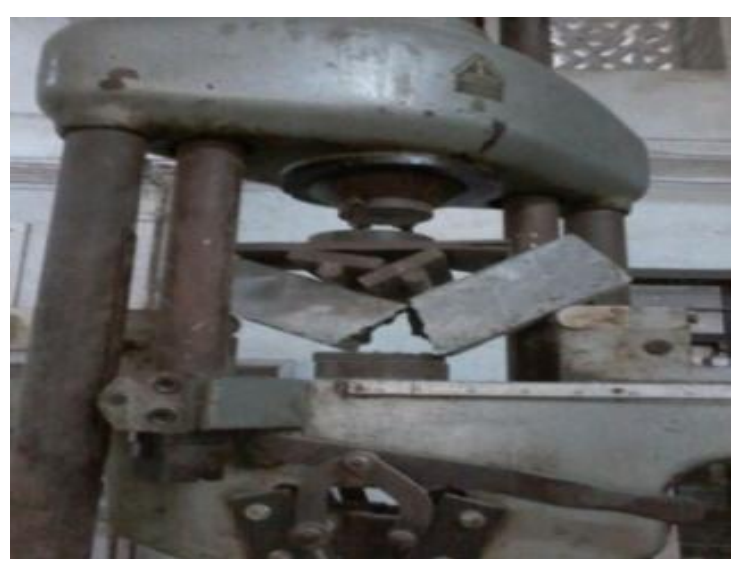

Plate 3.Test setup of Flexural strength

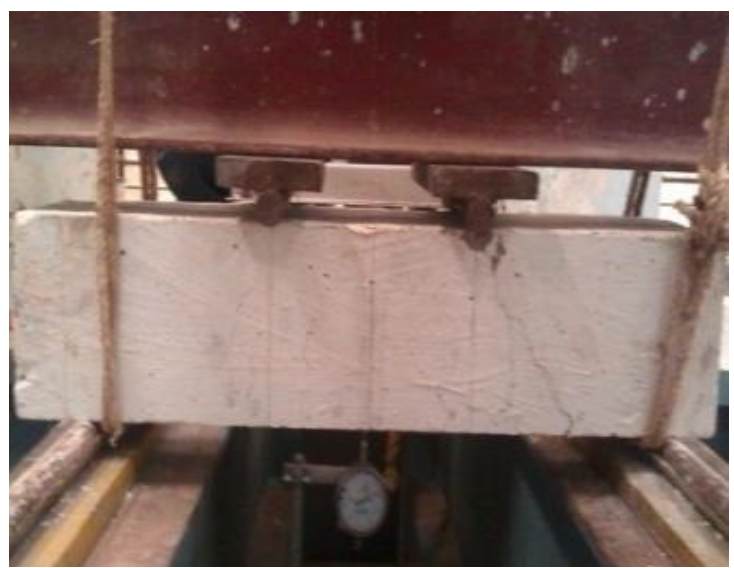

Plate 4.Test setup of Flexural strength

iii. POROSITY: After 28 days of curing, the cube specimens were removed from curing tank and dried. Now take the initial weight of cube specimens 
and noted the reading as unsaturated weight of cube and again take the of saturated weight of cube by immersing fully in the water tank and percentage of porosity is calculated. Test results are shown in table 3.

iv. WATER ABSORPTION:The dried specimens were cooled at room temperature and weighed accurately and noted as initial weight or dry weight of the specimen. Dry specimens kept again in a curing tank. Weight the specimen at predetermined intervals for every $12 \mathrm{hrs}$ i.e., $0,12,24,36 \ldots$. hrs was taken after wiping the surface with dry cloth. This process was continued up to constant weight was obtained in two successive observations. Graph was plotted as shown in fig.7.

\section{RESULTS AND DISCUSSION}

\section{Notations}

\begin{tabular}{|c|c|c|}
\hline S1..No & Designation & $\begin{array}{c}\text { \% sand Replacement of } \\
\text { CGF }\end{array}$ \\
\hline 1 & GF 0 & 0 \\
\hline 2 & GF 5 & 5 \\
\hline 3 & GF 10 & 10 \\
\hline 4 & GF 15 & 20 \\
\hline 5 & GF 20 \\
\hline \multicolumn{3}{|c|}{ For beams } \\
\hline 1 & CB & Conventional beam 0\% \\
\hline 2 & GF & Granite fines beam 15\% \\
\hline
\end{tabular}

Following are the graphs of strength and durability tests

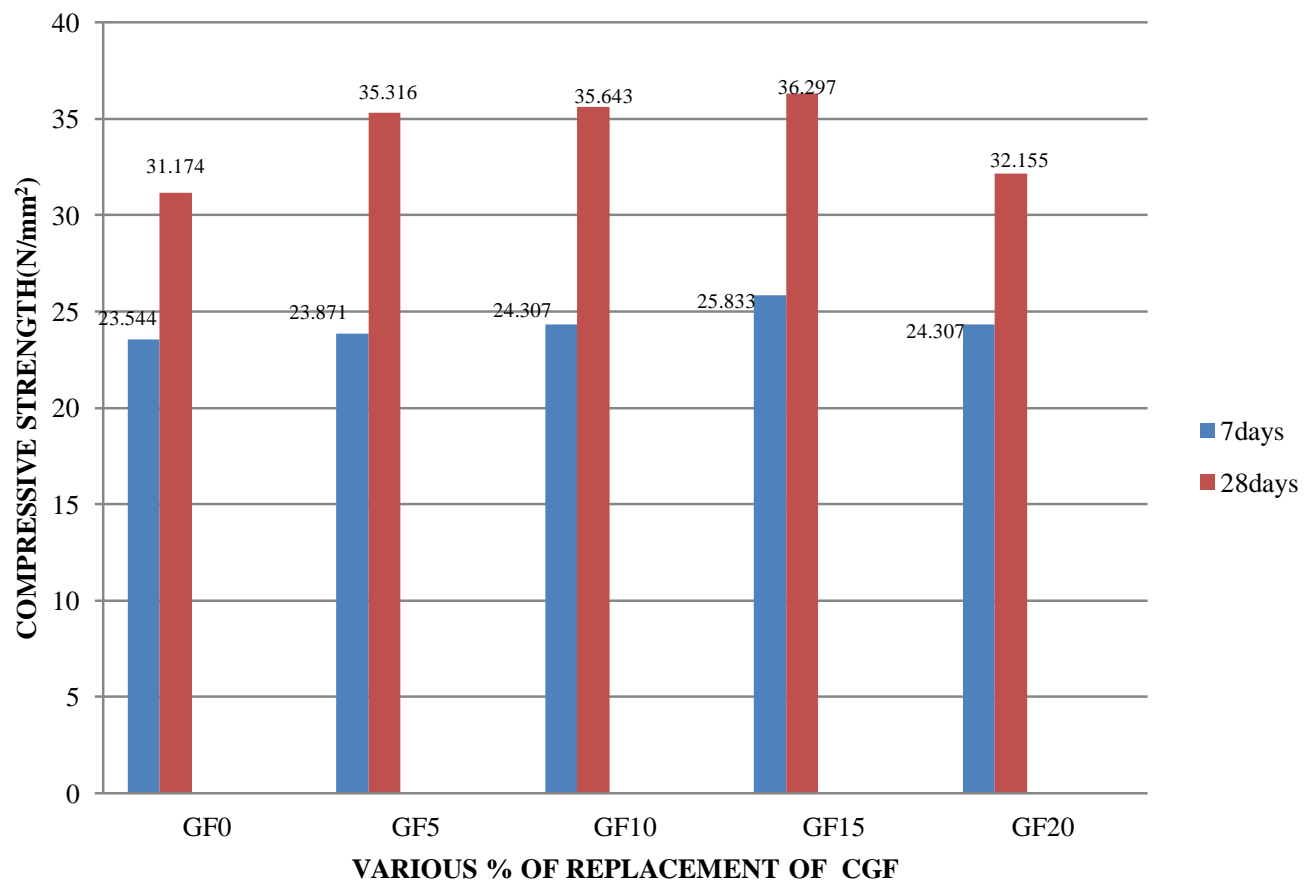

Fig 2.Compressive strength v/s \% of CGF replacement 


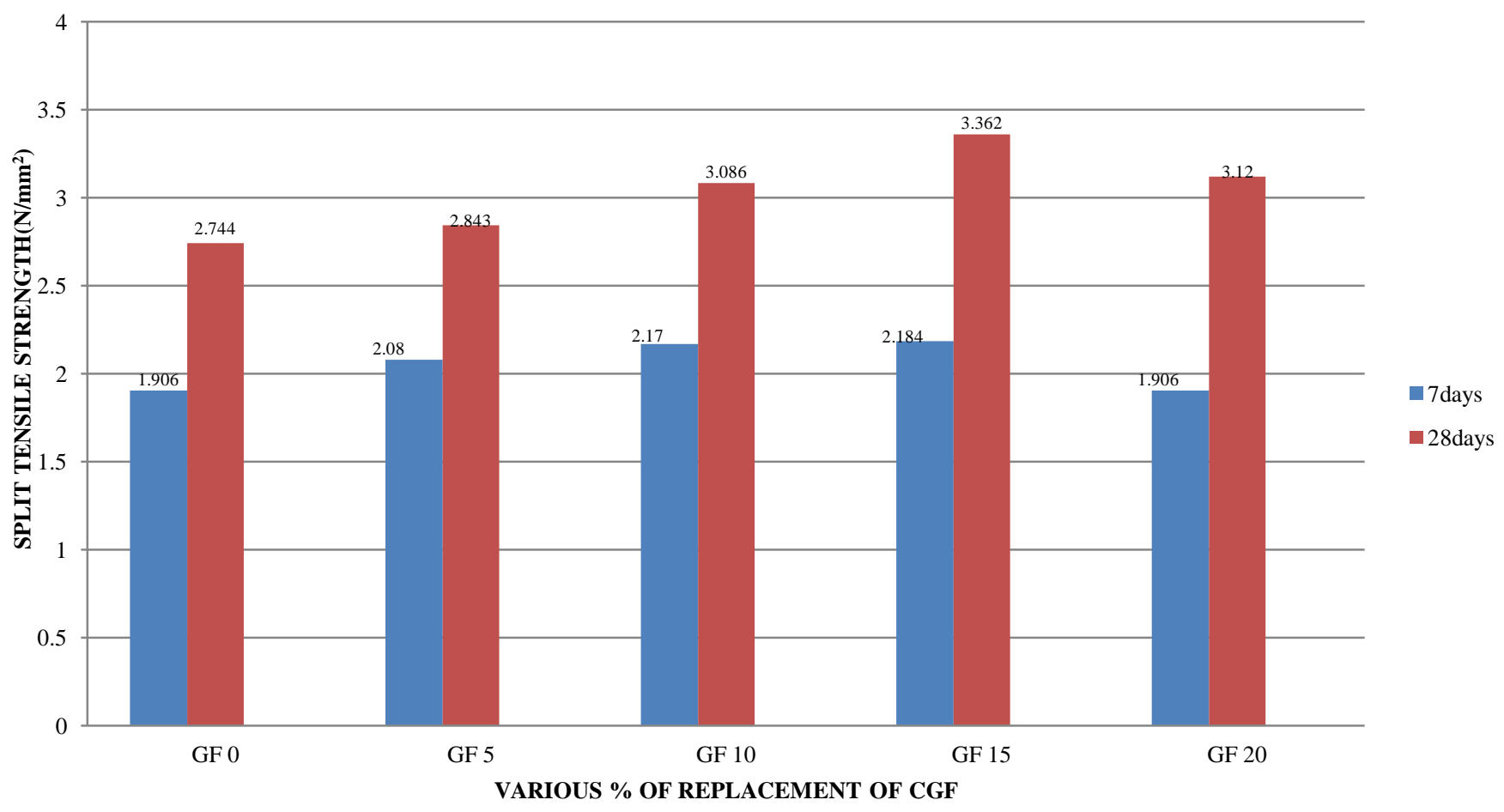

Fig 3.Split tensile strength v/s $\%$ of CGF replacement

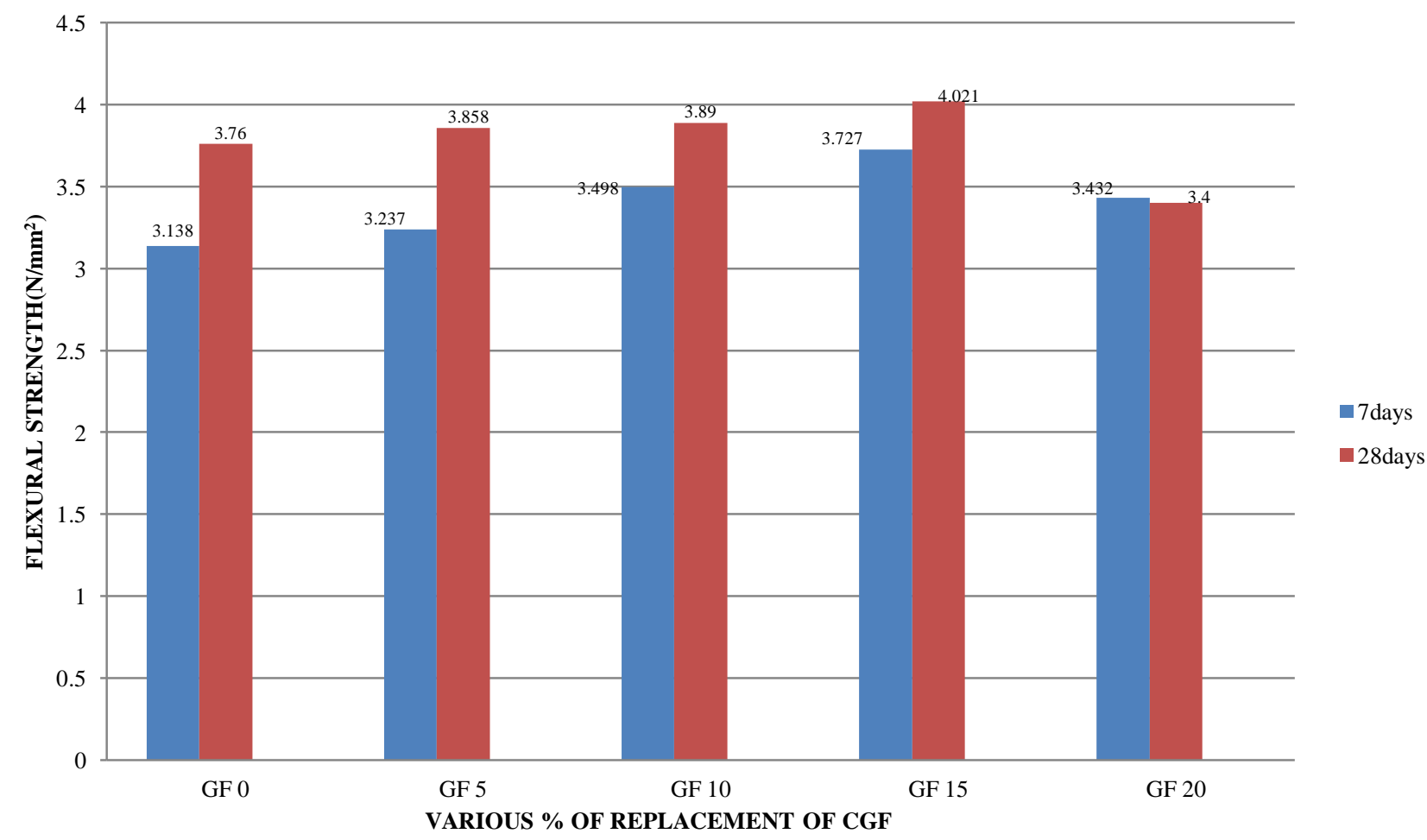

Fig 4.Flexural strength v/s \% of CGF replacement 
Table 2.Load and Deflection results for CB and GF

\begin{tabular}{|c|c|c|c|c|c|}
\hline S1 No & Designation & $\begin{array}{c}\text { Avg } \\
\text { Load(KN) }\end{array}$ & $\begin{array}{c}\text { Avg } \\
\text { Deflection(mm) }\end{array}$ & Avg Flexural strength(N/mm $\left.{ }^{2}\right)$ \\
\hline 1 & CB & 26 & 0.87 & $\begin{array}{c}1^{\text {st }} \text { crack load and } \\
\text { deflection }\end{array}$ & \multirow{2}{*}{16.23} \\
\cline { 3 - 5 } & 91 & 2.94 & $\begin{array}{c}\text { Ultimate load and } \\
\text { deflection }\end{array}$ & \multirow{2}{*}{17.89} \\
\hline 2 & GF & 24 & 0.71 & $\begin{array}{c}1^{\text {st }} \text { crack load and } \\
\text { deflection }\end{array}$ & \multirow{2}{*}{$\begin{array}{c}\text { Ultimate load and } \\
\text { deflection }\end{array}$} \\
\cline { 1 - 5 } & 100 & 3.29 & \multicolumn{2}{|c|}{} \\
\hline
\end{tabular}

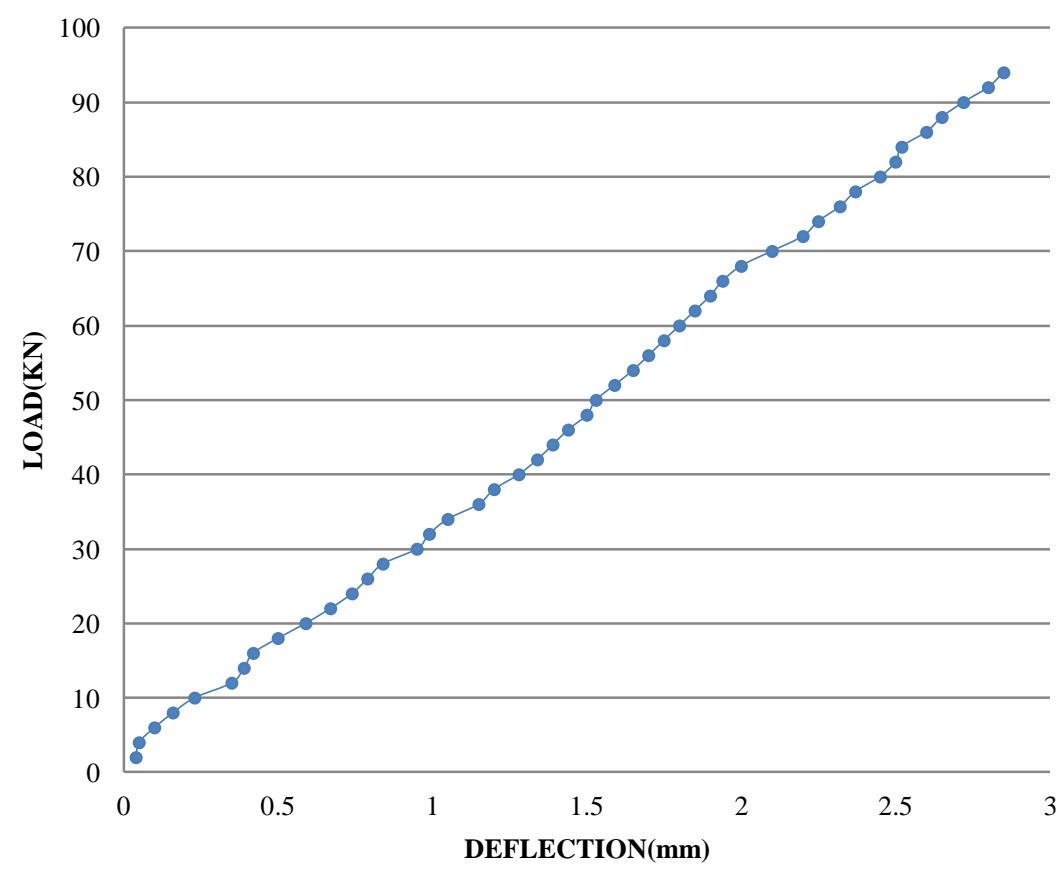

Fig 5.Load V/s Deflection curve for beam CB

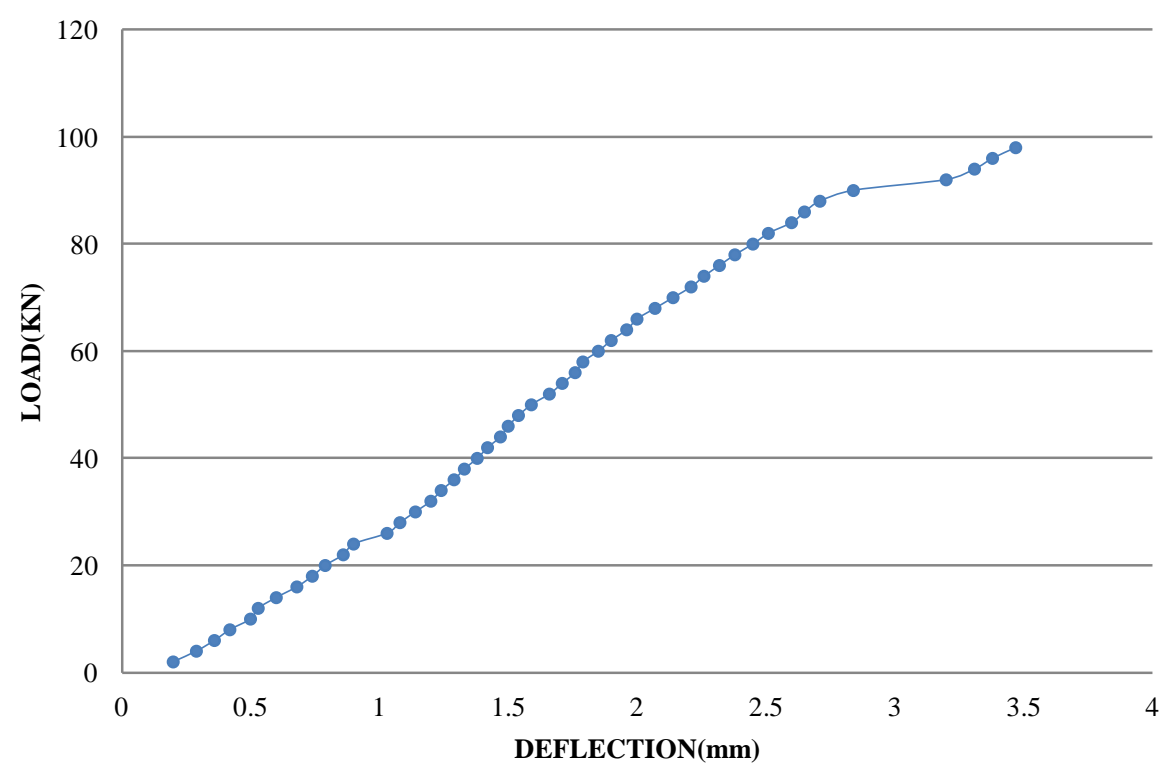

Fig 6.Load V/s Deflection curve for beam GF 


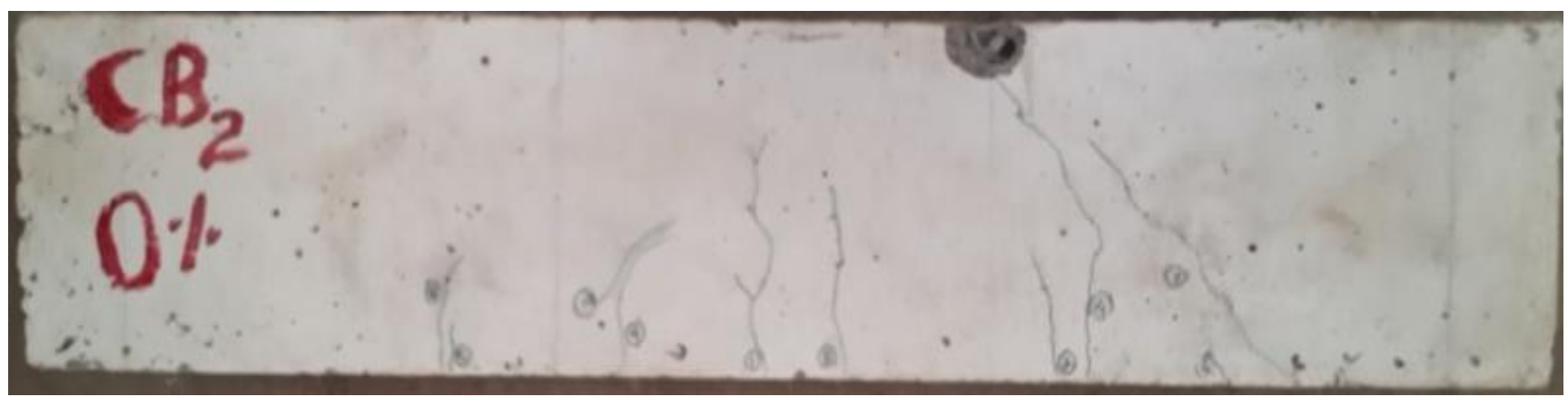

Plate 5.Failure pattern of conventional concrete beam CB

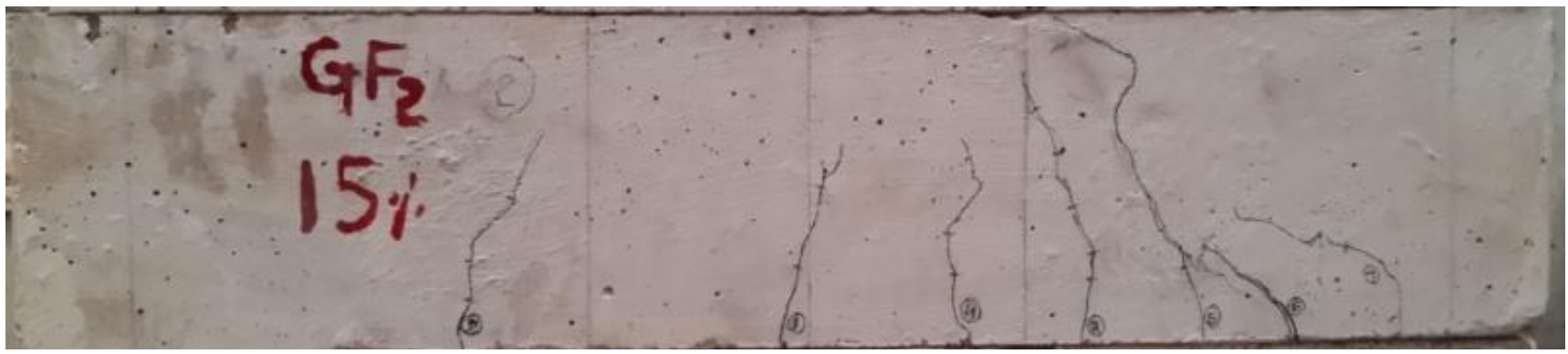

Plate 6.Failure pattern at optimum percentage beam GF

Table 3.Porosity test results

\begin{tabular}{|c|c|c|}
\hline $\begin{array}{c}\text { Sl } \\
\text { No }\end{array}$ & $\begin{array}{c}\text { CGF } \\
\text { replacement(\%) }\end{array}$ & Porosity(\%) \\
\hline 1 & GF0 & 18.82 \\
\hline 2 & GF5 & 18.28 \\
\hline 3 & GF10 & 13.38 \\
\hline 4 & GF15 & 11.10 \\
\hline 5 & GF20 & 11.06 \\
\hline
\end{tabular}

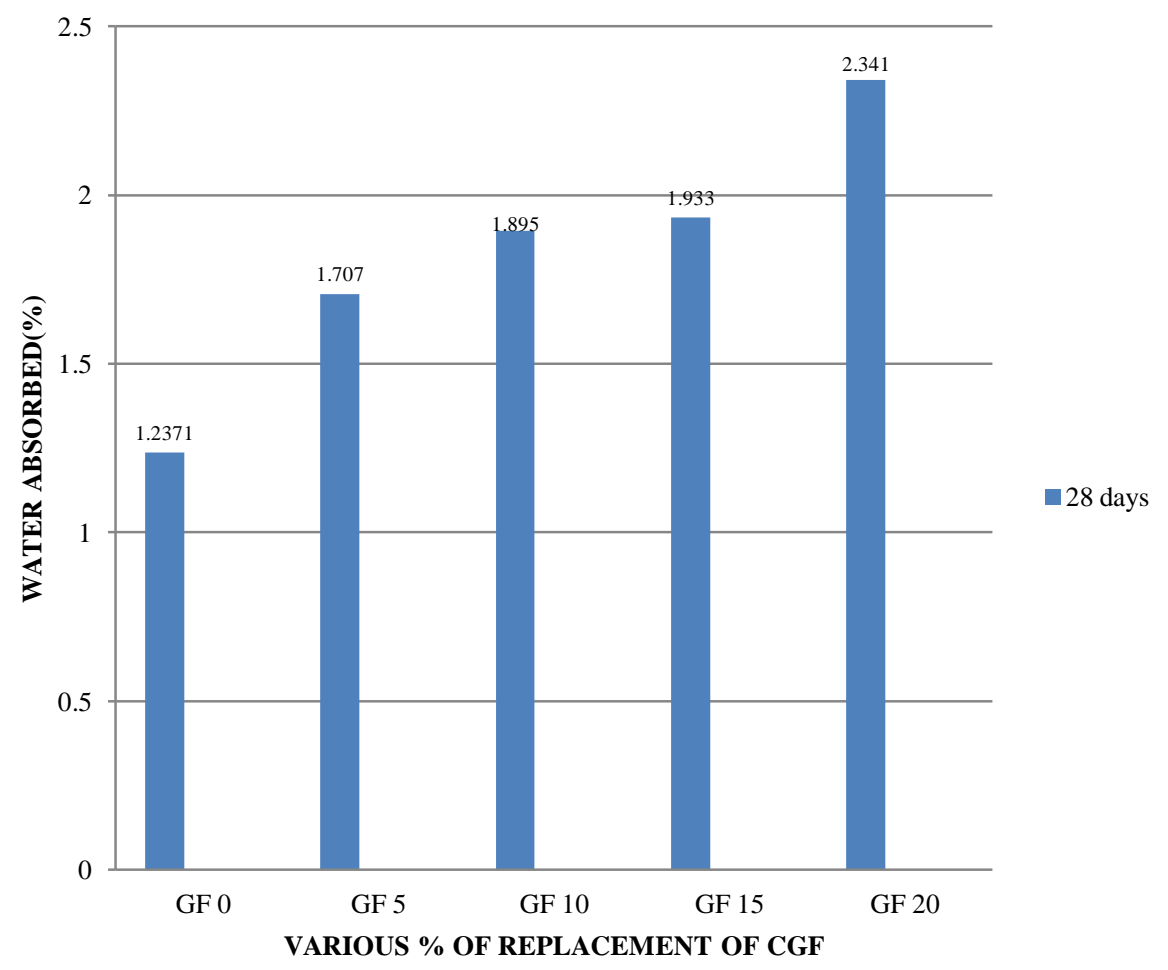

Fig 8. Water absorption v/s \% of CGF replacement 


\section{CONCLUSION}

It was arrived that optimum replacement of sand by Granite fines was $15 \%$ and following are the conclusions made with respect to conventional concrete.

1. Compressive strength of the concrete increases about $14.11 \%$.

2. Test result shows that the tensile strength of the concrete increases about $18.38 \%$.

3. Similarly an increase in flexural strength of $6.4 \%$ was noted for prisms and that for beams an increase in flexural strength of $9.31 \%$ was noted.

4. From the results it was observed that there is continuous decrease in porosity values for various percentage replacement of CGF when compared with that of conventional concrete. The porosity results indicate that CGF is more finer which fills the pores of concrete.

5. It has been observed that the water absorption value is continuously increasing for various percentage of replacement of sand by $\mathrm{CGF}$, which has negative effect.

\section{REFERENCES}

[1] Mr.A.Adin, Mr.T.SureshKannan and CONCRETE”, IRACST - Engineering Science and Technology: An International Journal (ESTIJ), ISSN: 2250-3498,Vol.3, No.1, February 2013.

[2] Rania A. Hamza, Salah El-Haggar, and SafwanKhedr, "Marble and Granite Waste: Characterization and Utilization in Concrete Bricks", International Journal of Bioscience, Biochemistry and Bioinformatics, Vol. 1, No. 4, November 2011.

[3] Manasseh JOEL, "Use of Crushed Granite Fine as Replacement to River Sand in Concrete Production", Leonardo Electronic Journal of Practices and Technologies ISSN 1583-1078 Issue 17, JulyDecember 2010 p. 85-96.

[4] S. AltafHussain, P. Shirisha, T. Shanti Kumar, S. Vamshi Krishna, Suggala. V. Satyanarayana "The use Granite industry waste as a cement substitute", International Journal of Engineering \&Technoligy(IJERT), Vol.2 Issue 9, September2013.

[5] BabooRai, Khan Naushad H, Abhishek K, TabinRushad S, Duggal S.K "Influence of marble powder or granules in concrete mix", INTERNATIONAL JOURNAL OF CIVIL AND STRUCTURAL ENGINEERING, VOL 1, NO.4, 2011.

[6] M. ShahulHameedand A. S. S. Sekar, "Properties of green concrete containing quarry rock dust and marble sludge powder as fine aggregate", ARPN Journal of Engineering and Applied Sciences, VOL. 4, NO. 4, JUNE 2009.

[7] R. Ilangovana, N. Mahendrana and K. Nagamanib, "Strength and durability properties of concrete containing quarry rock dust as fine aggregate",
ARPN Journal of Engineering and Applied Sciences, VOL. 3, NO. 5, OCTOBER 2008.

[8] T. Felixkalaand P. Partheeban, "Granite powder concrete", Indian Journal of Science and Technology, Vol. 3 No. 3 (Mar 2010). 